\title{
Thomas O. Mabbott As Teacher
}

\author{
PATRICIA EDWARDS CLYNE
}

In response to the late Professor Jay B. Hubbell's request to give an account of my husband's work on Poe, I wrote Mabbott as Poe Scholar, The Early Years. ${ }^{1}$ Its chief value, I think, is that I recorded there a past that only I am left to recall. At the end of my article TOM was back in New York City after teaching at Northwestern University and Brown University, without a publisher for his Poe, as Columbia University Press was unable to honor an earlier informal agreement. He was determined to go ahead, as I say there, at his own pace and at his own expense, and he was beginning what was to be a long term in teaching at Hunter College. Distinguished though it was, Hunter was a city college with the attendant heavy teaching load which included the teaching of composition. He chafed under the "injustice" of this kind of schedule for a scholar, but New York was his place, and teaching was his element. In his hands it had a give-and-take quality that was necessary to his adjustment to the world-he was stimulating to his students and they were an inspiration to him, one he never forgot. It follows that a full picture of Mabbott as Poe scholar includes Mabbott as teacher, and may I introduce the one person who can best give that picture, Patricia Edwards Clyne.

Maureen Cobb Mabbott

Thomas Ollive Mabbott was a legend at Hunter College by the time I arrived there as an undergraduate in the mid-1950s. In those days, what was called the Downtown Division of Hunter (as opposed to its uptown campus in the Bronx), located on Manhattan's Park Avenue, was still an all-girl school, and even the faculty tended to be predominantly female. In such a setting any male was bound to stand out, but with TOM it was much more than mere gender difference.

I heard about him long before I ever spoke with him, for I was in none of his classes during my first year there. Hence, I met the myth

1 Maureen Cobb Mabbott, Mabbott as Poe Scholar, The Early Years (Baltimore: Enoch Pratt Free Library, the Edgar Allan Poe Society, and the Library of the University of Baltimore, 1980). 
before I met the man, just as so many readers are introduced to the legendary Poe before they learn-if ever they do learn-about the real man. Fortunately, I came to know both: the real TOM and, through him, the real Poe. But that took many years, and perhaps it would be best to begin with my very first impression of Thomas Ollive Mabbott.

It was at the bank of elevators in the main-floor lobby of the Park Avenue building that the tall figure with the scholarly stoop was pointed out to me one autumn afternoon.

"That's him!" a classmate exclaimed. "That's Dr. Mabbott, the Poe scholar!"

Though my major would be journalism, I had long been intrigued by the work of Edgar Allan Poe, and so my interest was aroused.

"He knows more about Edgar Allan Poe than anyone else in the whole world," my classmate contended, "and he's just like him too!"

I could only stare in amazement, for the blue-eyed man with the graying blonde hair resembled no picture of Poe that I had ever seen. But before I could voice my disagreement, the girl added, "Oh, maybe not in looks, but I've heard people say that Dr. Mabbott has studied Poe for so long, he's almost become Poel"

Such melodramatic folderol delighted TOM, as I was to learn later, and he did nothing to dispel the myth. But just in case it has persevered, I should state that TOM certainly did not display any such psychological takeover during the last 15 years of his life when I knew him-first as his student, then as his assistant in preparing the long-planned edition of Poe. Admittedly, TOM did own a black cat (named Pluto-not Caterina), and on special occasions he did serve amontillado to his guests. However, that was the limit of his "Poeness," and the latter was only a demonstration of his innate courtesy, good humor, and love of the theatrical. "After all," he once told me, "I think people would be disappointed if I didn't offer them a glass -if not a cask-of amontillado."

This concern for other people was particularly evident in his relationship with students, for of all TOM's many interests, I believe he enjoyed teaching most of all. Nor was his teaching limited to the classroom. In the manner of the ancient Greeks he so much admired, TOM welcomed the company of students at all times, be it in the halls of Hunter, in his office in the Journalism Department, on a walk through midtown Manhattan, sharing a cab to the uptown campus, or in his large Lexington Avenue apartment where his gracious wife Maureen could always manage to find room for one more guest at the dinner table.

As a distinguished professor of English, TOM should have been 
ensconced in some office in that department's twelfth-floor dominion. Instead, he chose to share rather cramped quarters with the chairman of the Journalism Department, Martin J. Freeman, on the first floor. Part of this was due to certain physical infirmities which made the ground-floor office more convenient for TOM, but mostly it was because of the constant activity in the Journalism Department-activity which TOM enjoyed to the hilt, for he had an intense interest in journalism (and not only because Poe had been a newspaper writer and editor), admiring the "just the facts" style of a good reporter and conforming to such rules in his own writing. Being on the first floor likewise made TOM more accessible to his students, and that was very important to him.

When I say "his students," I am not referring only to those in his classes. Any Hunterite was "his student," along with many others from different schools who sought his help with undergraduate term papers, master's theses, and doctoral dissertations. (That, of course, does not include fellow scholars and authors who also asked for his assistance, and I have often wondered how many times the name of Thomas Ollive Mabbott has appeared in footnotes and/or acknowledgment sections. Surely if such a number could be determined, it would show him to be one of the most frequently cited scholars of modern times.) As I recall, he was always helping someone and not just with scholastic matters, though those were the most common.

One of the things which made TOM so "approachable"-at least in the eyes of Hunter students during those pre-women's-liberation days -was the fact that he considered women to be equal to men in all respects. He did not voice this in so many words, but his students at Hunter sensed this, and they loved him for it. They also liked the way he would immediately lay aside the New York Times (which he always read by resting the large sheets on one leg crossed over the other, the left ankle touching the right knee) whenever they approached his favorite olive green leather chair in the journalism office. And though few professors ever condescended to enter the student cafeteria, TOM considered it a privilege to be invited to join some of "his girls" for coffee there. He could be counted on for social functions as well, not all of which he enjoyed (afternoon teas bored him silly), but which he considered it his duty to attend if one of his students requested his presence.

His students reciprocated too. Since his love of the theater was well known, and his enthusiastic support of the various theatrical groups at Hunter was equally well appreciated, invariably there was a complimentary ticket with his name on it delivered to the journalism office on any opening night. And a holiday party was not a party 
without TOM, who would be asked to sing, in a somewhat off-key baritone, the fragment of a ballad that had been handed down in his family from its early days in England.

Many elements go into the making of a scholar: intelligence, analytical ability, and patience, to name only three. All of these qualities TOM possessed, as well as an interest in practically everything in the world-and beyond it too. However, if I were to select one other characteristic that contributed enormously to his greatness both as a scholar and a teacher, I would say it was his ability to listentruly listen-to what others had to say. This was the basis for one of the all-important lessons he tried to instill in his students, whether they planned to be teachers, actresses, nurses, journalists, or homemakers: that successful communication depends as much on "receiving" as it does on "sending," and that an attentive listener can almost always learn something from someone.

That TOM practiced what he preached can best be seen in the following anecdote that occurred shortly before I graduated from Hunter. As a college correspondent for the New York Times, I often stayed late at Hunter covering some evening event. On one such occasion, when I returned to the journalism office to type up my story and file it before the 9:00 P.M. newspaper deadline, I was surprised to find TOM still there, conversing with an elderly cleaning woman. From the gray tweed overcoat on his back and the battered brown briefcase under his arm, it was evident he had encountered the woman as he was leaving for home-but that destination seemed temporarily forgotten in his attention to what the woman was saying.

I detected the hint of a southern accent in the woman's speech as I excused myself and brushed past them on my way to the inner office, where I began typing up my story. More than a few minutes later TOM, overcoat still on, entered the room where I was working, grinning as happily as if he'd won a Pulitzer Prize. "Patsy Ann," he announced, "I have just had the most delightful conversation. Do let me tell you about it." And tell me he did, as the paper curled over forgotten in my typewriter, and the hands of the clock pushed toward 9:00.

TOM's "delightful conversation" had been initiated by an exchange of pleasantries with the elderly woman, who had entered the office to clean it just as TOM was on his way out. The woman had mentioned something about her childhood in the South, and from there the conversation had gone on to talk of superstitions, including the "evil eye"-something, the elderly woman assured TOM, that was strongly believed in by her parents and grandparents.

The story was interesting, I had to admit, but it escaped me why 
TOM was so delighted, until he explained, "Don't you see, Patsy Ann, this further substantiates that the belief was common down South around Poe's time-and you do know how he used the 'evil eye' to great effect in 'The Tell-Tale Heart."

I missed a newspaper deadline that night, but I learned a much more valuable lesson-in fact, more than one, which is why I chose to relate that particular anecdote here. Not only had TOM vividly demonstrated the importance of listening, even to those from whom no information of particular value is anticipated, but that the true scholar or investigator is never finished with the gathering of information. TOM had not needed that woman's reminiscences to prove that such a belief existed in the mid-nineteenth-century southland, but it delighted him to have come across one more scrap of substantiation.

This brief episode underscored still another of the out-of-the-classroom lessons TOM emphasized during my years at Hunter: the avoidance of what he called "academic snobbery." (Of course, I cannot speak for the time he taught at Northwestern University [1925-28] or at Brown [1928-29] or even for the complete period he was at Hunter [1929-66], but I doubt whether his attitude regarding this was ever any different.) TOM was no intellectual snob, and he had little patience with those who were. Though he was the most generous person I have ever known when it came to handing out praise for academic accomplishment, he did not automatically equate (as some people do) an academic degree with intellectual prowess. That there were "too many 'Ph. Dizzies' around" was a favorite phrase of his, and he frequently admonished his students to "respect the man, not the title."

In view of all this, it may be surprising to some that at one time TOM had the reputation of being exactly what he wasn't: an intellectual snob. This myth came about as a result of his open, and sometimes vociferous, objection to teaching freshman composition classes. He reasoned (and I think rightly so) that he would be of more value teaching only advanced courses, but his objection was misinterpreted by some to be predicated on mere snobbery. Happily, that baseless myth died when, toward the end of his stay at Hunter, TOM was no longer assigned to freshman composition courses.

Up to this point, I have avoided mention of TOM's classroom methods mainly because I wished to emphasize his total involvement with teaching. Just as Poe was always in his mind but not necessarily on his mind, TOM was a teacher at all times, whether "on duty" or not. Yet no picture of TOM as a teacher would be complete without a view of him in the classroom, for he was unquestionably unique.

Formality was a foreigner in any Mabbott classroom. Attendance 
was rarely if ever taken, students were encouraged to speak up as they wished, and the teacher himself often could be found sitting Indian-fashion atop his desk. Admittedly, such circumstances might not be considered so unusual in today's free-wheeling academic ambience, but it must be remembered that I am going back over 20 years to a more formal time, when Hunter students were required (under threat of expulsion, mind you) to behave in a "ladylike manner," and even the wearing of slacks was taboo except in the most inclement weather.

Added to this was the fact that TOM was a heavy smoker and blatantly ignored the college ban on smoking in the classrooms (the only such rule I ever knew him to break). Not only that, but he would allow his students to smoke also, on the condition they were to "leave no evidence of the misdeed"-the latter said with a conspiratorial chuckle.

He would then proceed to smoke one cigarette after another, long fingers rigidly extended, the cigarette more often than not held between the ring and middle fingers, leaving the thumb and forefinger free for any gestures, or in order to hold a book from which he was reading aloud. At other times, the ever-present cigarette might be left to dangle, seemingly forgotten, from the corner of his mouth as he sought to verbalize some idea, head thrown back to avoid the pluming smoke.

Unfortunately, some of the less mature students took this lack of formality to be the sign of an "easy marker" and that any class with TOM would be a "snap course." Nothing could have been farther from the truth. The ease with which he presented his material belied its depth and extent. And while he might not fail someone for poor attendance, it was hardly possible to pass one of his courses without being in class the majority of the time. In addition, he carefully marked all term papers, and woe betide the student who was slipshod or who cribbed. I remember the comment of one classmate who received a failing mark for the wholesale lifting of passages sans credit given to the original author: "Dr. Mabbott," she said, "must have read every book in the library, and can remember each one too!" Indeed, TOM's memory was so good that he could recite lines from obscure Greek lyric poets he had studied 30 years before, but he certainly hadn't retained everything he ever read. What the young woman didn't realize was that, despite his easygoing classroom manner, TOM was a sharp judge of human nature, and whenever a borderline student submitted an " $\mathrm{A}$ " paper he knew it was time to do some digging. Rarely was he compelled to do this, however, for the majority of his students were ensorcelled by this singular and charming man who 
seemed to know so much about so many things, and they worked to their full capacity.

Required reading was just that, and it was something to be done on the student's own time. Questions were answered or points amplified in class, but there was never a boring rehash of the subject or quizzes given just to see whether students had done their homework. TOM expected his students to be mature enough to do the reading he assigned. "This is college, not kindergarten," he asserted more than once, and he had no intention of wasting valuable class time on repetition or "imbecilic quizzes." On the other hand, he had infinite patience in explaining anything that a student sincerely had difficulty in comprehending. He would also take into consideration any plausible argument, even if it conflicted with his own views. The only thing he would not tolerate was absurdity.

Perhaps the most fascinating aspect of his classroom teaching was the way he pointed out interrelationships-how a theme used by one author in the nineteenth century had been treated similarly by an ancient Greek or a sixteenth-century playwright. In fact, he was responsible for initiating and carrying forward for a number of years a course in biography, which gave him an opportunity to range in one course from the Egyptians to the moderns.

His vast knowledge enabled him (without referring to notes) to highlight with anecdotes any subject under discussion. Oftentimes these anecdotes were of a somewhat scandalous nature, for TOM was well aware that a little bit of sensationalism could be the epoxy that permanently bonded some subject to a person's mind. Yet he was always the gentleman, never demeaning himself or his listeners with a downright dirty story or an off-color joke.

The main thrust of his teaching was not so much to help his students digest the contents of a certain course, but rather to spur them into proceeding on their own, seeking parallels and interconnections, sources, and sequential events, which would expand their understanding. For this reason TOM favored what he called "questionnaire term papers." Students were directed to select a certain literary work (the choice was up to them) and list any questions they might have regarding that piece. (For instance, if Poe's story "Ligeia" were chosen, a student might wonder where the author got the name of the protagonist, what was the meaning of that name, what kind of fluid was dropped into Rowena's goblet, etc.) Then, aided by research, the student answered these questions as fully as possible. It was a multipurpose assignment, and a good one, for not only was a student allowed to concentrate on what interested her most, but it also fostered the kind of independent study that other forms of term papers 
might not. Some of these studies, especially on Poe subjects, were rewarding to both student and teacher, and the results were acknowledged in TOM's Poe edition. See especially volume 1 of the Collected Works under Preface to the Proposed Edition, where he states a general debt to "my students," and other places where some are mentioned by name.

Because of his renown as a Poe scholar, there is a tendency to think of TOM only as an outstanding teacher of Poe. To do so is a disservice. In his role as a full professor of English, teaching a variety of courses, he was just as effective with Chaucer, Shakespeare, Boccaccio, Donne, Bronte, on up to and including modern-day British and American writers, the great and even the not so great. (How his students enjoyed his rendition of Robert W. Service's "The Shooting of Dan McGrew," usually quoted, with appropriate gestures, on a dark and snowy day when TOM felt "his girls" needed some cheering up. In warmer weather, or to celebrate the start of baseball season, he might open a class with "Casey at the Bat.") Nor should it be forgotten that he was regarded as an authority on Milton, having worked on the Columbia edition of that author's works published in the 1930s. Indeed, TOM may have been most comfortable in mid-nineteenthcentury America, but he was equally at ease in Johnson's eighteenthcentury England ${ }^{2}$ or Joyce's twentieth-century Ireland.

Generally speaking, a Mabbott classroom was a place of informal discussion, not a lecture hall. But when he did lecture, it was with a total grasp of his subject that could mesmerize an audience. Current events or holidays might spark him into lecturing extemporaneously on something not necessarily having anything to do with course content, and he was often asked to repeat such a talk (he preferred "talk" to "lecture") before a larger audience. He complied whenever possible and seemed especially pleased if the request were for "The History of Printing," a lecture which I, and many others, considered his best. It is unfortunate that it was never preserved in print.

What has been preserved in print, though not a recording of TOM's powerful rendition of it, is Poe's poem "Eldorado," and I would recommend it to anyone seeking to know the real TOM. This poem was TOM's favorite, for it echoed his own philosophy to

$$
\begin{aligned}
& \text { Ride, boldly ride . . . } \\
& \text { If you seek for Eldorado! }
\end{aligned}
$$

TOM boldly rode-and he inspired his students to do so too.

2 I am reminded that he was called to the University of California one summer to teach graduate courses in eighteenth-century literature simply on the strength of his articles on Chatterton and others in the London Notes \& Queries. 
THE PIERPONT MORGAN LIBRARY 33 East Thirty-sixth Street New York 16, N. Y.
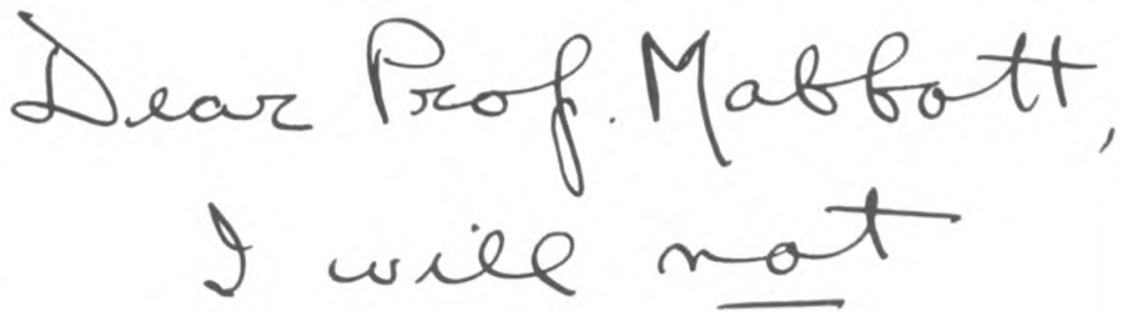

,

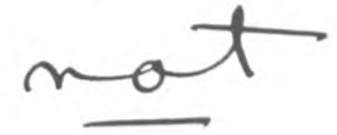

"spare

yo r
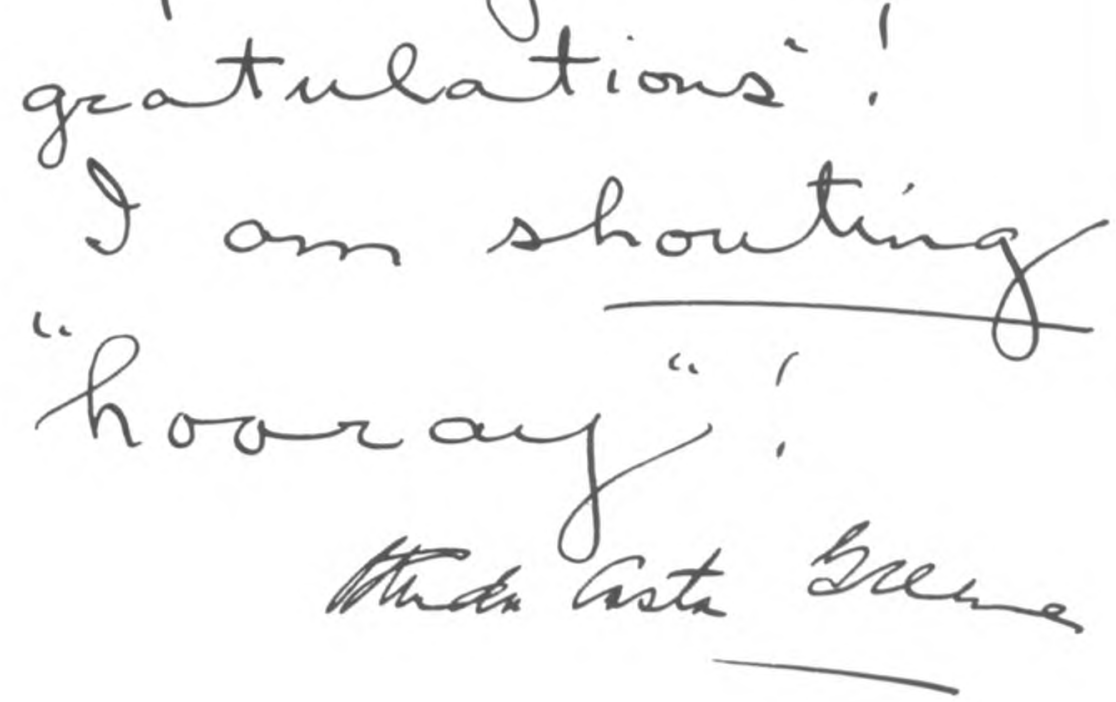

T. O. Mabbott's first meeting with Belle da Costal (rene. the highly regarded director of the Pierpont Morgan Library. took place in 1918 when he was only a junior in college. Miss Greene. who had a sure sense of values. announced then that she would reserve the manuscript of Poe's partially unpublished Politian for Mabbott's future doctoral dissertation. The above letter was written by Miss Greene 27 years later. in 1945, on the occasion of Mabbott's promotion to a full professorship at Hunter College. Original in the Mabbott Papers, The University of Iowa Libraries. reproduced with the concurrence of the Pierpont Morgan Library.

[26]

http://ir.uiowa.edu/bai/vol34/iss1 